Review

\title{
Food Safety and Fish Production the Case of Staphylococcus aureus: A Review
}

\author{
${ }^{1 *}$ Alejandro De Jesús Cortés-Sánchez, ${ }^{2}$ Mayra Díaz-Ramírez, \\ ${ }^{3}$ Ma. De la Paz Salgado-Cruz and ${ }^{4}$ Rocío G. Hernandez-Nava \\ ${ }^{1}$ Consejo Nacional de Ciencia y Tecnología (CONACYT), Unidad Nayarit del Centro de Investigaciones Biológicas del \\ Noroeste (UNCIBNOR+), Calle Dos, No. 23. Cd. del Conocimiento, Av. Emilio M. González C.P. 63173, Tepic, Nayarit, \\ México \\ ${ }^{2}$ Departamento de Ciencias de la Alimentación, División de Ciencias Biológicas y de la Salud, Universidad Autónoma \\ Metropolitana Unidad Lerma, Av. de las Garzas 10. Col. El panteón, Lerma de Villada, Estado de México, C.P. 52005 \\ ${ }^{3}$ Departamento de Ingeniería Bioquímica, Escuela Nacional de Ciencias Biológicas, Instituto Politécnico Nacional, Av. \\ Wilfrido Massieu Esq. Cda. Miguel Estampa s/n. Gustavo A. Madero, Ciudad de México. C.P. 07738 \\ ${ }^{4}$ Universidad Autónoma de Guerrero. Escuela Superior de Nutrición y Ciencia de los Alimentos, Carretera Cayaco-Puerto \\ Márquez, C.P.39906, Llano largo. Acapulco, Guerrero, México
}

Article history

Received: 17-10-2020

Revised: $30-12-2020$

Accepted: $31-12-2020$

Corresponding Author: Alejandro De Jesús CortésSánchez

Consejo Nacional de Ciencia y Tecnología (CONACYT), Unidad Nayarit del Centro de Investigaciones Biológicas del Noroeste (UNCIBNOR+), Calle Dos, No. 23. Cd. del Conocimiento, Av. Emilio M. González C.P. 63173. Tepic, Nayarit, México

Email: alecortes_1@hotmail.com

\begin{abstract}
Currently food safety must be a mandatory condition in food available for human and animal consumption. Food safety is considered the characteristic that these will not cause harm to the health of consumers. Foodborne diseases are considered a serious public health problem throughout the world due to their incidence, mortality and negative repercussions on the economic and productive sectors. Among the most frequent cases and outbreaks of foodborne illness is food poisoning resulting from the consumption of foods such as fish and products contaminated by Staphylococcus aureus and toxins. Staphylococcus aureus contamination of food can occur at any stage of the food chain, from primary production, processing, distribution, marketing, even manipulation by the final consumer; this mainly due to the absence or inadequate hygiene conditions and practices, establishing that this pathogen has the human being as its main reservoir and source of contamination. Therefore, the purpose of this manuscript is to provide general information through the search and analysis of information in different academic and scientific databases on foodborne diseases, causal agents of these diseases, especially Staphylococcus aureus, related foods in its transmission such as fish and tilapia, sources and conditions of contamination, as well as prevention and control actions in the different phases of the food chain in favor of food safety and public health.
\end{abstract}

Keywords: Aquaculture, Fishing, Food Pathogens, Foodborne Diseases

\section{Introduction}

The safety of a food is the guarantee that it will not cause harm or disease to the person who consumes it (De la Fuente Salcido and Corona, 2010; González-Muñoz and Palomino-Camargo, 2012; Jorquera et al., 2015). Also, it is an essential part of the quality characteristics of food, along with the nutritional, sensory and commercial ones (De la Fuente Salcido and Corona, 2010; González-Muñoz and Palomino-Camargo, 2012).

Foodborne diseases are considered a serious health problem worldwide due to their incidence, mortality, the appearance of new forms of transmission, vulnerable population groups, increased resistance of pathogenic microorganisms to antimicrobials and socioeconomic impact (González Flores and Rojas Herrera, 2005; Olea et al., 2012; Soto Varela et al., 2016; WHO, 2020a). According to estimates from the World Health Organization (WHO), one in 10 people worldwide falls ill and 420,000 die a year, especially children (WHO, $2020 b$ ). These diseases are identified by presenting various symptoms in the gastrointestinal system, such as: Nausea, vomiting, diarrhea, abdominal pain and fever; presenting in severe cases complications such as sepsis, meningitis, 
abortions, Reiter's syndrome, Guillan Barré syndrome, even death; and where the most vulnerable population groups to these diseases are children, the elderly, pregnant women, people with poor immune systems and those with high levels of poverty and poor hygiene conditions (Torrens et al., 2015; Soto Varela et al., 2016).

These diseases are derived from the consumption of food contaminated by more than 250 causal agents that can have a physical, chemical and/or biological origin (De la Fuente Salcido and Corona, 2010; Barreto Argilagos et al., 2010; Olea et al., 2012; Torrens et al., 2015; Soto Varela et al., 2016). This contamination can be generated at any stage of the food chain (from farm to table), thus losing its safety (De la Fuente Salcido and Corona, 2010; WHO, 2020a). Among the casual agents of biological origin are bacteria such as Salmonella spp., Vibrio spp., Aeromonas spp., Campylobacter spp., Shigella spp., Yersinia spp., Clostridium spp., Bacillus cereus, Escherichia. coli, Listeria monocytogenes and Staphylococcus aureus, commonly related to cases and disease outbreaks (De la Fuente Salcido and Corona, 2010; Barreto Argilagos et al., 2010; Olea et al., 2012; Jorquera et al., 2015; Torrens et al., 2015; Soto Varela et al., 2016). It has been established that among the factors that have contributed to the increase in the incidence of foodborne diseases are globalization in the food supply, changes in food production systems (minimal processing), emergence of antimicrobial resistant pathogens, along with the acquisition of virulence factors, climate change, demographic changes, changes in the lifestyle and eating habits of society such as the consumption of packaged foods, meals outside the home, the sale of prepared meals and fast foods (Olea et al., 2012; Jorquera et al., 2015; Torrens et al., 2015; VázquezSánchez et al., 2018).

Foodborne diseases caused by bacteria can be: (A) Foodborne infections originating with the consumption of a food contaminated by the pathogen that is established and multiplies in the consumer and that has two variants: (1) Invasive infections: Characterized by the microorganism colonizing host's tissues and organs such as bacteria of the genus Salmonella spp., Aeromonas spp., Campylobacter spp., Shigella spp., Vibrio spp., Yersinia spp. and entero-invasive Escherichia coli. (2) Toxin-infections: Those bacteria capable of colonizing and multiplying in the host's intestinal tract, where they excrete their toxins, such as: Vibrio cholerae, Bacillus cereus (enterotoxin-producing strains), Clostridium botulinum, Clostridium perfringens and enterotoxin-producing Escherichia coli or verotoxins; and (B) Food poisoning derived from toxins produced by bacteria that grew to a certain concentration in the food. Some microorganisms are: Clostridium botulinum, Bacillus cereus (producers of emetic toxin) and Staphylococcus aureus (Torrens et al., 2015).
The appearance of these diseases is considered an indicator of the hygienic-sanitary quality of food, where the contamination of food can occur in its processing, or use of contaminated raw materials where various bacteria pathogenic to humans can be a constituent part of the microbiota of animals destined for consumption (González Flores and Rojas Herrera, 2005).

The purpose of this article is to provide a general description of foodborne diseases, causal agents of these diseases such as Staphylococcus aureus, related foods such as fish and tilapia, sources of contamination, as well as prevention measures and control in the different phases of the food chain in favor of food safety and public health.

\section{Fish}

Fish is all food extracted from fresh or brackish waters intended for human or animal consumption (Soares and Goncalves, 2012). The source of fish for humans is through capture fisheries and aquaculture activities where, according to estimates by the United Nations Food and Agriculture Organization (FAO) for the year 2018, the total world production was 178.5 million tons in live weight and a per capita consumption of $20.5 \mathrm{~kg}$ (FAO/WHO, 2020). Fish is considered a food source of protein with high digestibility and biological value, as well as unsaturated lipids, vitamins and minerals (Sousa et al., 2011; Soares and Goncalves, 2012; Fuertes Vicente et al., 2014; Ali, 2014). However, it is also a highly susceptible to contamination and deterioration food due to factors such as its $\mathrm{pH}$ close to neutrality, water activity and high nutrient content (Sousa et al., 2011; Soares and Goncalves, 2012; Ali, 2014).

Among the factors involved in the deterioration of fish are the autolytic, chemical (oxidation) and microbiological activity, thus affecting its quality and safety (Huss, 1998; Soares and Goncalves, 2012; Fuertes Vicente et al., 2014). The nutritional quality, freshness and safety of the fish vary depending on factors such as the species, age, conditions of the environment in which they live, type of feeding, conditions of capture, handling, conservation, transport and distribution (Fuertes Vicente et al., 2014). Microbial activity plays a primary role in the deterioration and safety of fish and products due to numerous microorganisms present in the water, as well as the natural microbiota (Sousa et al., 2011). The microbiota of fish is found on all external surfaces (skin and gills) and intestines, where the total number of microorganisms varies enormously and is highly dependent on the capture environment and species (Huss, 1997; 1998; Sousa et al., 2011).

The microorganisms that are part of the fish microbiota represent an interest in terms of quality and 
safety, since various genera and species of bacteria can cause human diseases. The bacterial microbiota in fish is made up of two groups: 1. Native species widely distributed in aquatic environments around the world, where water temperature clearly has a selective effect. Among these groups are Clostridium botulinum, Listeria monocytogenes, Vibrio spp., Aeromonas spp. and Plesiomonas spp. 2. Various Enterobacteriaceae nonnative bacteria such as Salmonella spp., Shigella spp., Escherichia coli and Staphylococcus aureus as a product of contamination of the aquatic environment they come from and due to poor production and handling conditions in the matter of hygiene (Huss, 1997; Romero-Jarero and Negrete-Redondo, 2011; Ali, 2014).

In fish, the microbial load depends, to a large extent, on the microbiological contamination of the aquatic environments, as well as the hygienic-sanitary level during the handling in cultivation, harvest, processing, storage and transportation practices (Alerte et al., 2012; Fuentes et al., 2011; Fuertes Vicente et al., 2014). Aquaculture and fishing activities are widely distributed and provided with food, which has been related to outbreaks and cases of diseases; therefore, fish are considered potential carriers and transmitters of pathogens to humans, being the most relevant Escherichia coli, Staphylococcus aureus, Salmonella spp., Listeria spp., Aeromonas spp. and Vibrio spp., (Romero-Jarero and Negrete-Redondo, 2011; Alerte et al., 2012; Fuentes et al., 2011; Espinosa et al., 2015; Vázquez-Sánchez et al., 2018; Ampuero et al., 2018; Bujjamma and Padmavathi, 2015).

\section{Tilapia}

Tilapias are freshwater fish of African origin that belong to the Cichlidae family and are classified into three genera based on their parental care patterns: Tilapia spp., Oreochromis spp. and Sarotherodon spp. (Baltazar, 2007; Jácome et al., 2019). The species of the genus Oreochromis (O. niloticus, O. aureus, $O$. mossambicus) and their interspecific hybrids (red tilapia) have been considered as aquaculture organisms due to their ability to tolerate high densities, have a fast growing rate, resistant to diseases, easily adaptable to captivity, balanced diet and their meat is a source of quality protein and affordable price as a complete product or processed as fresh or frozen fillets, becoming an important food product of aquaculture with greater production and commercialization (Morales et al., 2004; Vázquez-Sánchez et al., 2018; Jácome et al., 2019), being reported in 2018 a global aquaculture production within the finfish of $10.2 \%$ (FAO/WHO, 2020).

Tilapia is considered a nutritious food for humans, a source mainly of proteins $(20.08 \mathrm{~g} / 100 \mathrm{~g})$, lipids (1.7 g/100 $\mathrm{g})$, vitamin D (3.1 mg/100 g), B3 (3.9 mg/100 g), B9 (24 $\mathrm{mg} / 100 \mathrm{~g})$ and minerals as $\mathrm{Na}(52 \mathrm{mg} / 100 \mathrm{~g}), \mathrm{K}(302$ $\mathrm{mg} / 100 \mathrm{~g})$ and $\mathrm{P}(170 \mathrm{mg} / 100 \mathrm{~g})$ (SAGARPA, 2018). Globally, China is the main producer, followed by Bangladesh, Brazil, Philippines and Mexico (SAGARPA, 2018). Eight different species are produced in Mexico: (1) tilapia rendalli, (2) Oreochromis niloticus, (3) Oreochromis niloticus variety Stirling, (4) Oreochromis niloticus variety Rocky Mountain, (5) Oreochromis. aureus, Oreochromis mossambicus, (6) Oreochromis mossambicus variety orange, (7) Oreochromis urolepis hornorum and (8) Oreochromis sp. (Oreochromis mossambicus $x$ Oreochromis urolepis hornorum) being the main producing states of the country: Chiapas, Jalisco, Guerrero, Michoacán, Morelos, Nayarit, Estado De Mexico, Puebla, Veracruz, Sinaloa, Zacatecas and Tabasco (INP, 2018; SAGARPA, 2018). Within food production activities such as fishing, aquaculture, processing and conservation of tilapia and products, there is a risk of microbiological contamination involving a risk to safety and public health; the extensive variation of microorganisms in tilapia may be due to geographical particularities, environmental conditions, depth and existing microorganisms in the water it comes from and hygienic handling and processing conditions. Some microbial genera especially linked to products are: Aeromonas spp., Micrococcus spp., Staphylococcus spp., Bacillus spp., Pseudomonas spp., Plesiomonas spp., Listeria spp., Clostridium spp., Lactobacillus spp., Helicobacter pylori, Moraxellaceae and Enterobacteriaceae (Shigella ssp., Salmonella spp., Enterobacter spp., Klebsiella spp., Proteus spp., Serratia spp., Edwardsiella spp., Morgenella spp., among others), for which it becomes essential to identify points of contamination, prevalence of microbial species and consider strategies to avoid the dissemination of microorganisms throughout the food chain in order to guarantee the quality and final safety of products (Morales et al., 2004; Boari et al., 2008; Atyah et al., 2010; Shinkafi and Ukwaja, 2010; Junior et al., 2014; Fuentes et al., 2011; Echandi and Ulate, 2012; da Rocha et al., 2013; Abdel-Moein et al., 2015; Kang et al., 2017; Vázquez-Sánchez et al., 2018; Sheyin and Solomon, 2017; Lerma-Fierro et al., 2020).

\section{Staphylococcus aureus}

Staphylococci are organisms of universal distribution located in water, air, soil, wastewater, food, as well as surfaces and all articles that come into contact with humans and animals, where the nose has been established as its main reservoir, along with the throat, skin and intestinal tract and estimating that the rate of human carriers can be from 30 to $60 \%$ of healthy individuals (Huss, 1997; Acha and Szyfres, 2001; Cortés Sánchez et al., 2017).

Members of the genus Staphylococcus are considered Gram positive bacteria in the form of cocci, grouped in clusters with a diameter between 0.5 
and $1.5 \mu \mathrm{m}$, facultative anaerobes, catalase positive, no capsules producers, not sporulated, not motile, with a guanine-cytosine ratio $(\mathrm{G}+\mathrm{C})$ from 30 to $39 \%$ (Acha and Szyfres, 2001; Zendejas-Manzo et al., 2014; Cortés Sánchez et al., 2017). This genus has been reported to have 32 species, 16 of which are considered opportunistic microorganisms (Cortés Sánchez et al., 2017). The most important species from a clinical and food safety perspective, since they are generators of infectious and intoxications, are: Staphylococcus aureus, Staphylococcus lugdunensis, Staphylococcus intermedius, Staphylococcus haemolyticus, Staphylococcus epidermidi, Staphylococcus saprophyticus, Staphylococcus hominis subsp. hominis, Staphylococcus warneri, Staphylococcus simulans, Staphylococcus capitis subsp. ureolyticus, Staphylococcus auricularis, Staphylococcus cohnii subsp. Urealyticum (Cortés Sánchez et al., 2017).

Staphylococcus aureus is a pathogen that presents several virulence factors that in combination with the decrease in host's defenses, lead to colonization and diseases. Some of these factors are cytotoxins (alpha, beta, gamma and delta), nucleases, proteases, lipases, hyaluronidase, catalase, coagulase, collagenase, leucocidin; different Toxins Such as Toxic Shock syndrome (TSST-1), enterotoxins (SE) and exfoliative toxins, in addition to structural components such as peptidoglycan, protein A, adhesion factors, teichoic acids, capsular polysaccharides and the generation of biofilms (Cervantes-García et al., 2014a; Zendejas-Manzo et al., 2014; Cortés Sánchez et al., 2017). Staphylococcus aureus gives rise to infections and conditions such as osteomyelitis, septic arthritis, abscesses, pneumonia, empyema, endocarditis, pericarditis, meningitis and diseases mediated by its toxins including food poisoning, scarlet fever, scalded skin syndrome and toxic shock syndrome (Arteaga Bonilla and Arteaga Michel, 2005).

Staphylococcus aureus is the etiological agent of one of the most frequent diseases caused by the consumption of contaminated food, such as food poisoning (Brizzio et al., 2011; Macori et al., 2016). Common symptoms can appear between 2 and $4 \mathrm{~h}$ after consuming contaminated food, those are nausea, vomiting, abdominal spasm, diarrhea and hyperthermia. Symptoms typically last 24 to $72 \mathrm{~h}$ with a tendency to recovery, but in severe cases, dehydration can lead to hypotension, shock and collapse (Huss, 1997; Acha and Szyfres, 2001; Jorda et al., 2012). Poisoning generally originates from the consumption of foods with mainly protein content, subjected to poor hygiene practices in handling and storage, where the growth of Staphylococcus aureus is greater than 5 Log ColonyForming Units (CFU)/g and enterotoxins are present (Acha and Szyfres, 2001; Jorda et al., 2012; Macori et al., 2016; Vázquez-Sánchez et al., 2018; Elika, 2020). Raw and ready-to-eat foods such as dairy, fish, chicken, eggs, meats and vegetables are usually the most related to food poisoning by this pathogen (Huss, 1997; Cortés Sánchez et al., 2017; Elika, 2020).

The enterotoxins of Staphylococcus aureus (SE) do not affect the sensory characteristics of contaminated food, they are water-soluble compounds, low molecular weight, resistant to proteolytic and thermostable enzymes synthesized in the growth phase after the exponential, encoded in mobile genetic elements, such as prophages, plasmids and islands of pathogenicity and genomic islands (Huss, 1997; Brizzio et al., 2011; Jorda et al., 2012; Zendejas-Manzo et al., 2014; Cortés Sánchez et al., 2017; Vázquez-Sánchez et al., 2018; Wakabayashi et al., 2018; Elika, 2020). Their genetic expression is controlled by at least three regulation systems: Agr, sar and, a catabolic repression system, in addition to being influenced by factors such as the type of nutrients, substrate $\mathrm{pH}$, temperature, atmosphere, $\mathrm{NaCl}$ and competing microorganisms (Huss, 1997; Brizzio et al., 2011; Jorda et al., 2012; Zendejas-Manzo et al., 2014; Cortés Sánchez et al., 2017; Vázquez-Sánchez et al., 2018; Elika, 2020). Five types of enterotoxins (SE) are known (A, B, C, D and E), which are the most frequent in food poisoning, with $\mathrm{A}$ being the most prevalent in outbreaks (Acha and Szyfres, 2001; Cortés Sánchez et al., 2017; Wakabayashi et al., 2018) and where it has been estimated that the dose of toxins to produce disease is 1 to $5 \mu \mathrm{g} / \mathrm{g}$ food (González Ayala and Cecchini, 2020). In addition to the fact that coagulase positive Staphylococcus aureus strains are those that are mainly related to disease outbreaks, because very few coagulase negative strains are capable of producing enterotoxins (Acha and Szyfres, 2001; Zendejas-Manzo et al., 2014; Macori et al., 2016).

Staphylococcus aureus is a mesophilic microorganism with a minimum development temperature of $10^{\circ} \mathrm{C}$, facultative anaerobic, tolerance to $\mathrm{NaCl}(7.5 \%)$ and capable of developing water activities as low as 0.86 and a minimum $\mathrm{pH}$ of 4.5 for development (Huss, 1997; Cervantes-García et al., 2014a). Staphylococci are poor competitors and do not thrive in the presence of other organisms, therefore the presence of Staphylococci in naturally contaminated raw foods can be considered of limited relevance. However, in precooked foods contaminated with Staphylococcus aureus and under suitable conditions of time and temperature, rapid development and production of toxins can occur (Huss, 1997).

Staphylococcal contamination of food is generally related to an absent or poor hygiene practice in any of the phases of the food chain, being humans part of the ecological niche; contamination is mainly decanted in direct contact phases by food handlers in processing (Jorda et al., 2012; da Rocha et al., 2013; Vázquez-Sánchez et al., 2018; Cortés Sánchez et al., 2017). Furthermore, Staphylococcus aureus can form biofilms on food contact surfaces that 
increase its tolerance to stress conditions, as well as its persistence and contamination in environments related to food generation (Vázquez-Sánchez et al., 2018).

\section{Actions to Control Food Safety and Prevention of Diseases Caused by Staphylococcus aureus}

The responsibility for food safety is shared as it involves the government health authorities as well as those who produce process and market them and it is an obligation to ensure they are safe. However, there may be oversights or omissions in this regard, which are reflected in a risk and a damage to the consumers' health (González Flores and Rojas Herrera, 2005; GonzálezMuñoz and Palomino-Camargo, 2012). Fish can be contaminated at any stage of the production chain from primary production, handling after capture, processing, conservation and storage, being determinants for the quality of the final product (Farias and Freitas, 2008; Sousa et al., 2011; Bujjamma and Padmavathi, 2015; Vázquez-Sánchez et al., 2018). Therefore, the sanitary regulation establishes different microbiological indicators and limits to the presence in food to guarantee safety and quality (Farias and Freitas, 2008; Vázquez-Sánchez et al., 2018). There are different microorganisms that indicate contamination and sanitary risk, such as Staphylococcus aureus, whose study is of relevance for the surveillance of the hygienic quality of fishery products due to its relationship in the generation of diseases through food (Romero-Jarero and Negrete-Redondo, 2011).

Fish have a microbiota that is dependent on what it exists in the waters where they live, meaning that polluted waters can provide a variety of pathogens; the microorganisms in the skin and gastrointestinal content of the fish in life do not invade the sterile muscle package due to the protection of its natural defenses. When the animal dies, these microorganisms penetrate the fish, causing deterioration and loss of safety. The presence of Staphylococcus aureus in fish and products can mainly indicate contamination from the skin, mouth and nostrils of infected handlers or healthy carriers, during stages of capture, transport, storage, processing and preparation processes (Huss, 1997; Romero-Jarero and Negrete-Redondo, 2011).

In order to guarantee safety in the production of fish and products, the need for the implementation of good hygiene practices and conditions, Sanitation Standard Operating Procedures (SSOP), as well as Hazard Analysis and Critical Control Points (HACCP) systems has been established in the different phases of the food chain (aquaculture, fishing, handling, processing, elaboration and preservation of products) which include compliance with microbiological criteria of raw materials susceptible to contamination by Staphylococcus aureus, the control of temperature maintaining the cold chain $\left(<6^{\circ} \mathrm{C}\right)$ during transport, storage and distribution of food to avoid microbial development or keep food with $\mathrm{pH}<5$, in addition to the control of health and hygiene of the personnel that handles and elaborates food in order to avoid contamination, proliferation and production of staphylococcal toxins in fishery products (Huss, 1997; Acha and Szyfres, 2001; CXC/RCP, 1969; OMS, 2007; Fitzsimmons, 2008; Kopper et al., 2009; OMS, 2016; Goulding, 2016; Gutiérrez-Guzmán et al., 2017; Elika, 2020).

In regards of control and prevention of food poisoning by Staphylococcus aureus through fish, different sanitary regulations have been established around the world. In Latin American, countries such as Mexico, through the National Service of Health, Safety and Food Quality (SENASICA acronym in Spanish) has published the manual for the implementation of good aquaculture practices in primary fish production including those for tilapia farming (SENASICA, 2019), as well as the official standard "(NOM-242-SSA12009)", within its sanitary regulation, establishes the microbiological criteria (Staphylococcus aureus and toxins) for fishery products, with a maximum limit of $1000 \mathrm{CFU} / \mathrm{g}$ of product and absence of toxins and "(NOM-251-SSA1-2009)" establishes the requirements for good hygiene practices for the food process and specifies the principles for the implementation of the HACCP system. Finally, the standard "(NMX-F, 2016)" involves the hygienic handling in the service of food prepared in fixed establishments and so they can obtain the Distinctive "H" recognition the Ministry of Tourism and the Ministry of Health provide to those establishments that have met the hygiene standards.

In South America, countries such as Peru, ministerial resolution "(SA/DM, 2003)" establishes the microbiological criteria for food and beverages for human consumption in the national market must comply, where for chilled or frozen raw hydro biological products (Fish) the microbiological criteria for Staphylococcus aureus the maximum allowable limit is $10^{3} \mathrm{CFU} / \mathrm{g}$. While in Central America through the Central American Technical Regulation of food safety as "(RTCA 67.04.50:17. ICS 67.050, 2018)" establishes the microbiological criteria for Staphylococcus aureus in raw products, such as frozen or refrigerated fish, the permitted limit of $10^{2} \mathrm{CFU} / \mathrm{g}$ of product for commercialization and consumption in the territory of countries in the region such as Guatemala, Salvador, Costa Rica, Nicaragua, Honduras and Panama.

In the European Union, food safety is established in different regulations throughout the food production 
chain. Some of these regulations are regulation $(\mathrm{CE})$ No 178/2002 (OJEU, 2002), which establishes the principles and general requirements of the food legislation and the European Food Safety Authority is created and procedures related to food safety are established. While regulation (EC) No 852/2004 (OJEU, 2004a) establishes general rules for food, business operators in the matter of hygiene of food products, that includes the general application of procedures based on the principles of Hazard Analysis and Critical Control Points (HACCP). Meanwhile, regulation (EC) No 853/2004 (OJEU, 2004b) establishes specific rules for food business operators regarding the hygiene of food of animal origin and the regulation (CE) No 854/2004 (OJEU, 2004c) established for the organization of official controls of the products of animal origin destined for human consumption. Regulation (CE) No 882/2004 (OJEU 2004d) on official controls carried out to guarantee the verification of compliance with the legislation on feed and food and the regulations on animal health and animal welfare. Directive 96/23 CE (Directive,1996) that refers to the control measures applicable to certain substances and their residues in live animals and their products, including aquaculture and regulation (EC) No 2073/2005 (OJEU, 2005), which establishes microbiological criteria applicable to food, including fishery products for their acceptability, safety and marketing.

\section{Laboratory Analysis}

Regarding the control and prevention of food poisoning by Staphylococcus aureus, the detection and isolation of the pathogen in food is an essential part of the process; for that, various analytical methodologies have been developed around the world, some of them have standardized that involve isolation and enumeration through the use of selective and differential culture media (Baird-Parker, mannitol salt agar, Staphylococcal agar No. 110, DNAse agar), as well as biochemical identification tests (catalase, coagulase and thermonuclease) for colonies with characteristic or typical growth (Zendejas-Manzo et al., 2014) (Table 1). Among the standard developed methods are that of (Tallent et al., 2019) in the U.S. Food and Drug Administration (FDA) through the Bacteriological Analytical Manual (BAM), where the method involves isolation and enumeration of Staphylococcus aureus, generating dilutions of the sample with phosphate-saline buffer and $1 \% \mathrm{NaCl} .1 \mathrm{~mL}$ of the dilution is distributed on three plates of Baird Parker agar $(0.4,0.3$ and $0.3 \mathrm{~mL})$ and incubated for $45-48 \mathrm{~h}$ at $35-37^{\circ} \mathrm{C}$. Colonies of typical growth are selected (circular, smooth, convex, moist, 2-3 $\mathrm{mm}$ in diameter, gray to black in color, surrounded by an opaque area and frequently with a light outer area of buttery to rubbery consistency) and confirmation from biochemical tests (coagulase, catalase, anaerobic utilization of glucose and mannitol and thermonuclease). Likewise, the method of the Most Probable Number (MPN) recommended for the regular surveillance of foods in which small amounts of Staphylococcus aureus and/or population of competing species are expected is established. For which, using 3 tubes with trypticase soy broth with $10 \% \mathrm{NaCl}$ and $1 \%$ sodium pyruvate, they are inoculated with $1 \mathrm{~mL}$ of the diluted sample and incubated at $48 \pm 2 \mathrm{~h}$ at $35-37^{\circ} \mathrm{C}$. Baird-parker agar is inoculated from each tube and incubated for $48 \mathrm{~h}$ at $35-37^{\circ} \mathrm{C}$. The growing colonies are subjected to biochemical confirmation tests (coagulase, catalase, anaerobic use of glucose and mannitol and thermonuclease).

For their part, the United States Department of Agriculture (USDA) and the Food Safety and Inspection Service (FSIS) are assisted in their regulatory activities with The Microbiology Laboratory Guidebook (MLG) that contains test methods for the isolation and identification of different food pathogens such as Staphylococcus aureus through quantitative analysis as a sanitary indicator in fish and other foods (MLG 3.02). The MLG 3.02 method involves a direct plate count for Staphyloccoccus aureus through dilution and homogenization of the sample and inoculation in differential and selective culture medium such as BairdParker, as well as the confirmatory biochemical test (coagulase activity) for colonies with typical growth (Fig. 1) (USDA, 2020).

Another widely used standard method is from International Organization for Standardization (ISO) ISO 6888 Microbiology of food and animal feeding stuffsHorizontal method for the enumeration of coagulasepositive staphylococci (Staphylococcus aureus and other species). ISO 6888-1:1999/AMD (2018) Technique using Baird-Parker medium, (ISO 6888-2:1999) Technique using rabbit plasma fibrinogen agar medium and (ISO 6888-3, 2003) Detection and Most Probable Number (MPN) technique for low numbers.

Meanwhile, in Latin America in Mexico, the official sanitary regulation through the official standard "(NOM210-SSA1-2014; NMX-F-310-1978)" that establish the methods for the microbiological analysis of sanitary indicators and food pathogens such as Staphylococcus aureus in the food (Figs. 2 to 4 ) indicating that frozen fish samples subject to analysis must be thawed in refrigeration $\left(2-5^{\circ} \mathrm{C}\right)$ a maximum of $18 \mathrm{~h}$ before analysis. On the other hand, in South America in countries like Peru, the Ministerial Resolution 
"(MINSA, 2007)" establishes the technical guide for the hygiene analysis of surfaces in contact with food, including live surfaces (food handlers) focused on sanitary control. Likewise, alternative methods have been developed for the detection of Staphylococcus aureus and toxins in food based on immunoassays (Suárez-Semour and González, 1990; Figueroa et al., 2002; Brizzio et al., 2013).

Table 1: Biochemical identification characteristics for Staphylococcus aureus isolates (NOM-210-SSA1-2014; Tallent et al., 2019)

\begin{tabular}{llll}
\hline Test & Staphylococcus aureus & Staphylococcus epidermidis & Micrococcus \\
\hline Catalase activity & + & + & + \\
Coagulase activity & + & - & - \\
Thermonuclease & & - & - \\
activity & + & + & - \\
Glucose fermentation & + & - & - \\
Mannitol fermentation & + & &
\end{tabular}

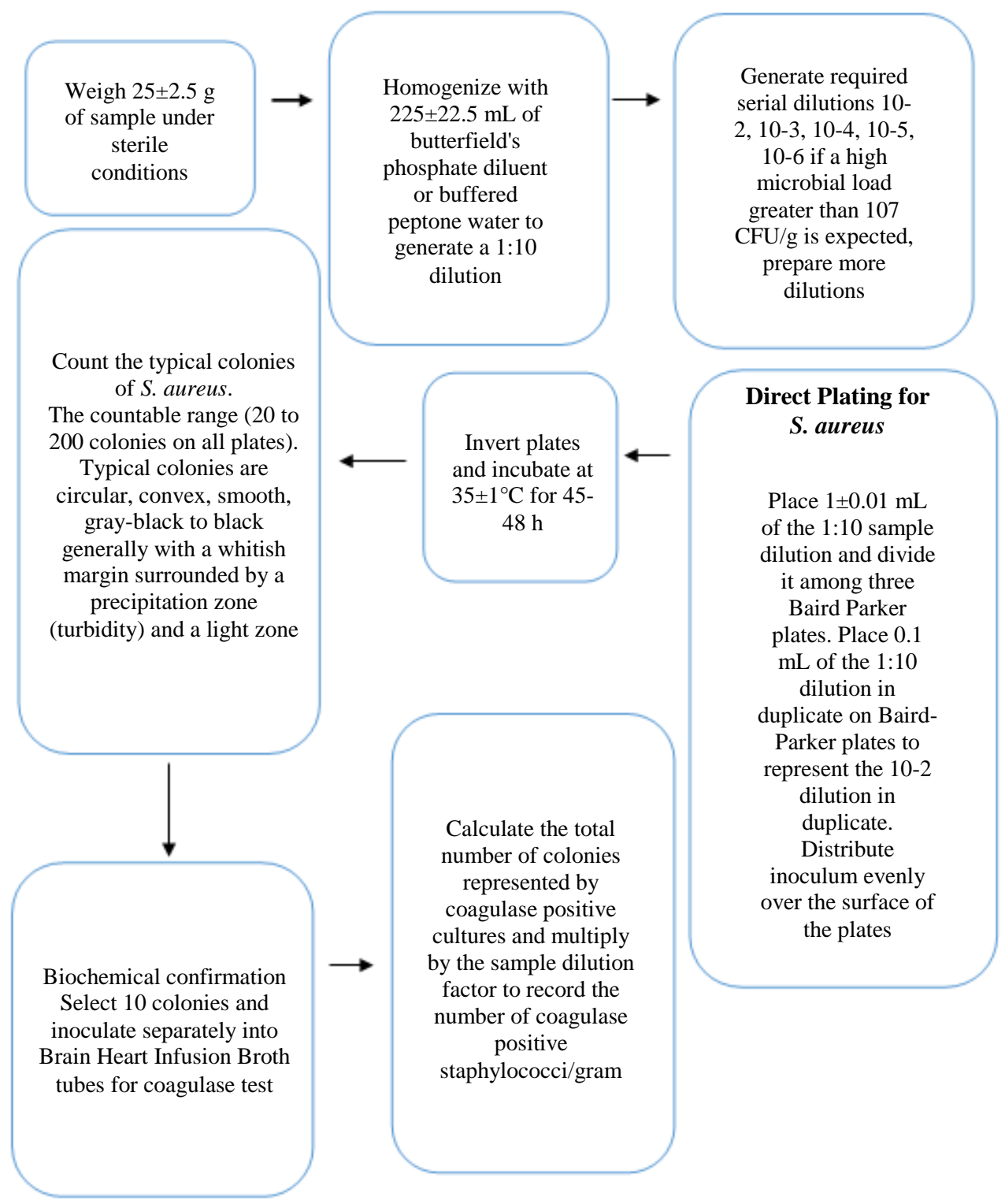

Fig. 1: Flow diagram for isolation and quantification of Staphylococcus aureus (MLG 3.02) (USDA, 2020) 


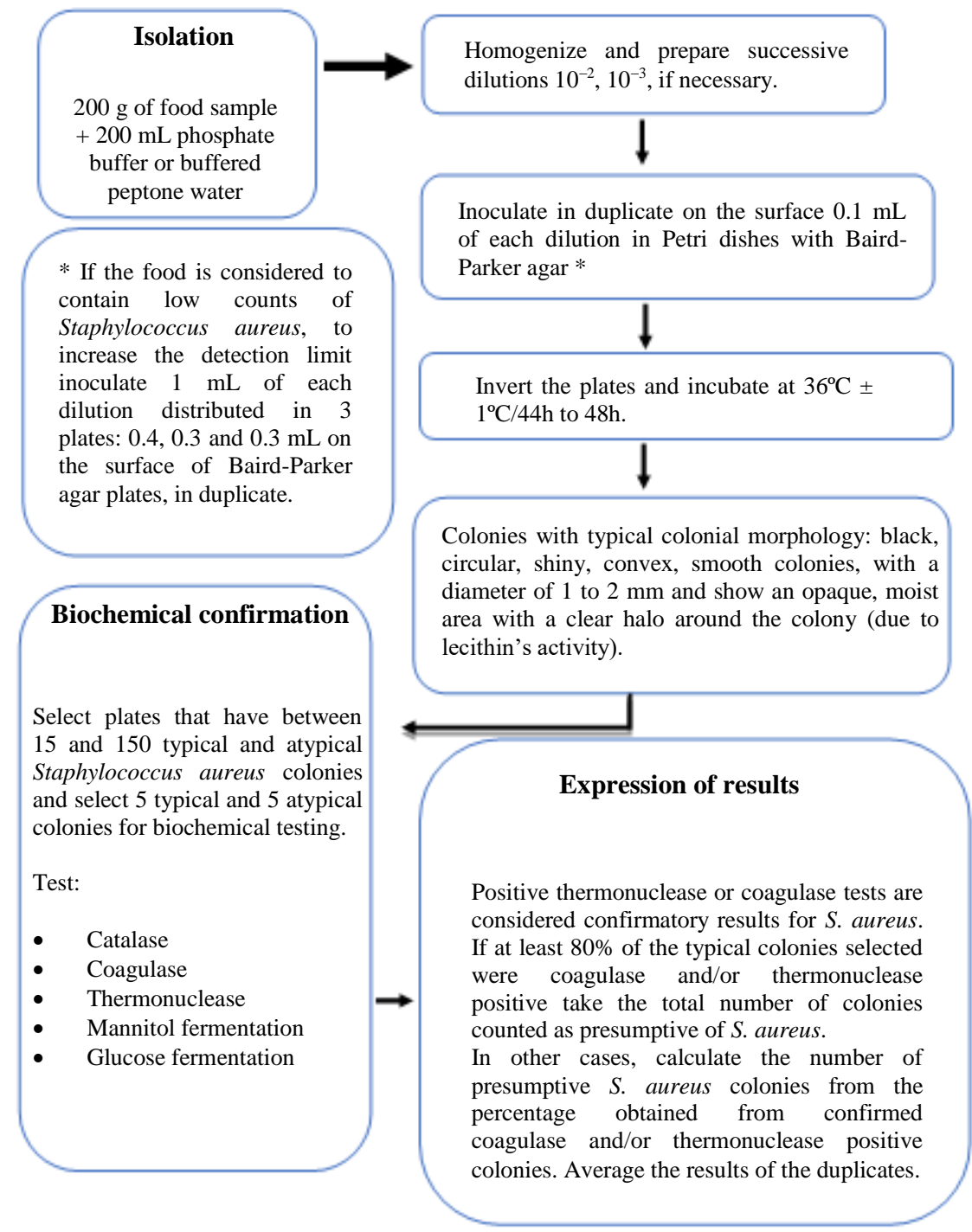

Fig. 2: Flow chart for the isolation and enumeration of Staphylococcus aureus in food (NOM-210-SSA1-2014)

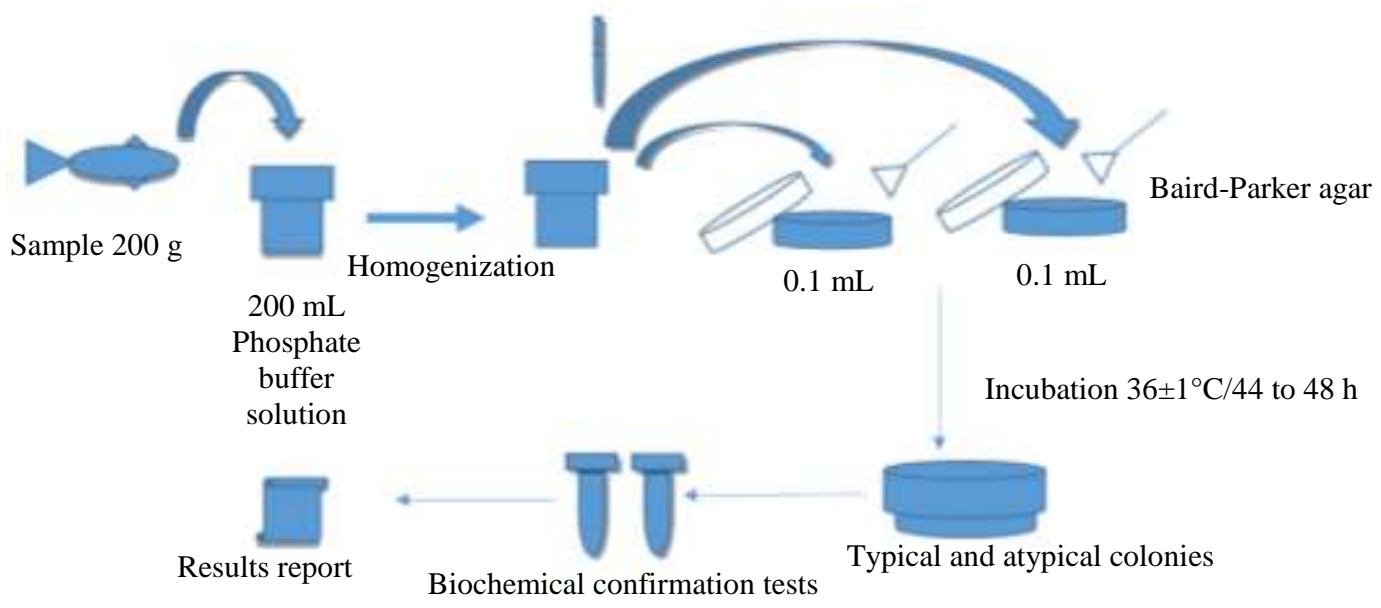

Fig. 3: Scheme of work for the isolation and enumeration of Staphylococcus aureus in fish (NOM-210-SSA1-2014) 


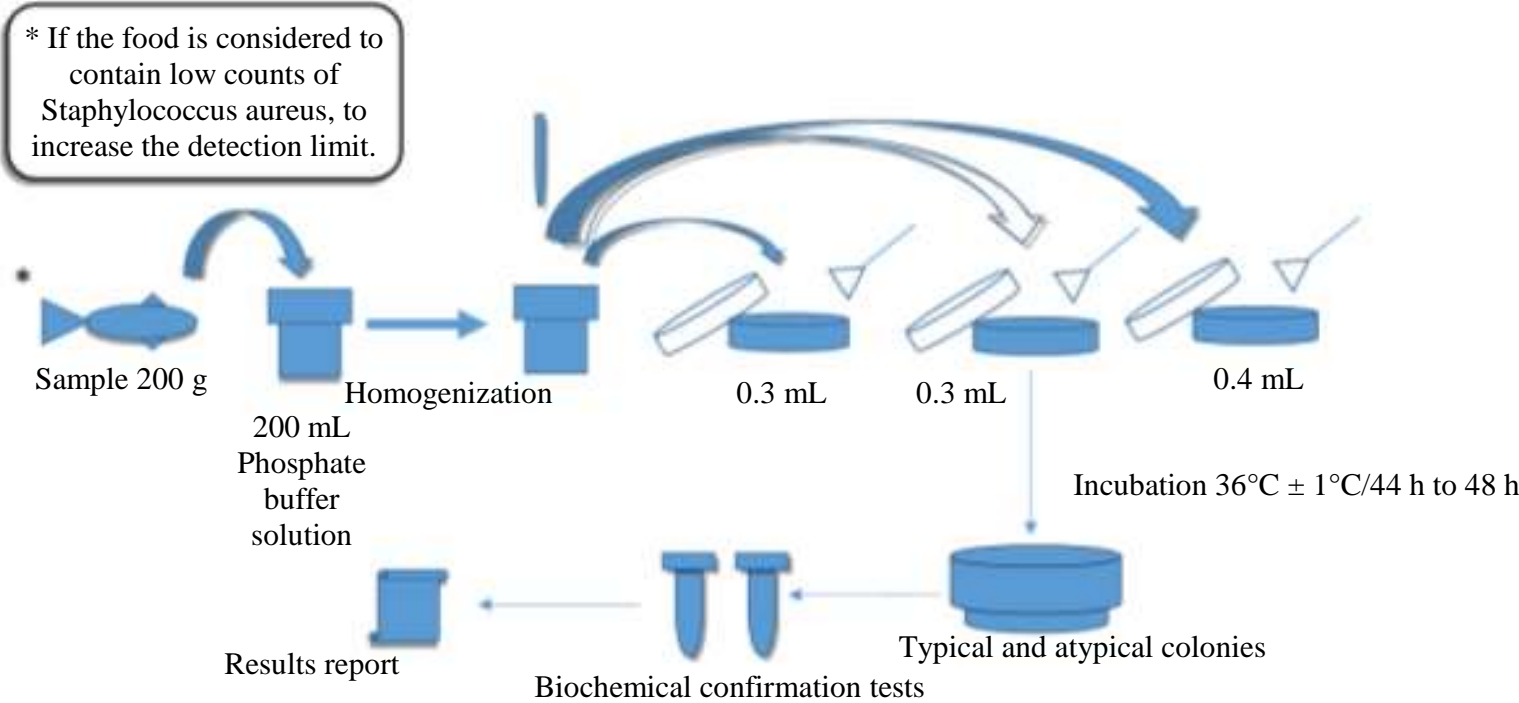

Fig. 4: Scheme of work for the isolation and enumeration of Staphylococcus aureus in fish (NOM-210-SSA1-2014)

Also, molecular methods based on the Polymerase Chain Reaction (PCR) in its different variants using the respective target genes encoding mainly enterotoxins (SE) (sea, seb, sec, sed, see and 16S rDNA) have been developed. These methods allow a greater number of samples to be analyzed, greater sensitivity, specificity and speed in obtaining results compared to traditional methods, they also allow epidemiological, evolutionary and phylogenetic studies (Manfredi et al., 2010; Saito et al., 2011; Jorda et al., 2012; Brizzio et al., 2013; Palomino-Camargo and González-Muñoz, 2014; Arfatahery et al., 2016; Wakabayashi et al., 2018; Hussein et al., 2019).

\section{Antimicrobial Resistance by Staphylococcus aureus and Food Safety}

Antimicrobial resistance is defined as the ability of a microorganism to resist the inhibitory activity of its growth or death by a certain antimicrobial (Verraes et al. 2013). Antimicrobial resistance has been considered a threat and a serious problem for human and animal health worldwide for several years (Puig Peña et al., 2019; FAO/WHO, 2020).

The increase in resistant microorganisms, being mainly bacteria, impacts on public health due to the increase in morbidity and mortality rates due to infections, extension of periods of disease and increased health costs (Peña et al., 2011). Resistance to antimicrobials by bacteria can be naturally acquired as a product of chromosomal mutations and exchange of genetic material with other bacteria or phages, by mechanisms of transformation, transduction, transposition and conjugation (Becerra et al., 2009; Verraes et al., 2013; Calderón Rojas and Aguilar Ulate, 2016). The different resistance mechanisms are: Modification of the permeability of the membrane, extraction of the compound by efflux or expulsion mechanisms, enzymatic inhibition, modification of the attack target or alteration of the composition and content of the cell wall glycoproteins and formation of biofilms (Becerra et al., 2009; Peña et al., 2011; Verraes et al., 2013; Gestal et al., 2014; Calderón Rojas and Aguilar Ulate, 2016).

Antimicrobial resistance in bacteria has been considered to be derived from a synergy in the excessive and inappropriate use of antimicrobials in humans and animals; and in the latter, antimicrobials are used for different purposes such as therapeutic, prophylactic and growth promotion for food production (Puig Peña et al., 2019; Verraes et al., 2013). Antimicrobial resistance affects food safety as food plays an important role in the development and spread of antimicrobial resistance by microorganisms; in addition to being the production systems and food chains a potential route of exposure together with the environment and water (Puig Peña $e t$ al., 2019; FAO/WHO, 2020).

So far and among the main foodborne pathogens that have been reported with antimicrobial resistance are: Staphylococcus aureus, Escherichia coli, Clostridium perfringens, Listeria spp., Salmonella spp., Campylobacter spp., Vibrio spp. and Shigella spp. (Junod et al., 2013; Calderón Rojas and Aguilar Ulate, 2016; Elmahdi et al., 2016; Cáceres et al., 2017; Weiler et al., 2017). In the case of Staphylococcus aureus, the isolation of strains resistant to various Antimicrobials Such as Resistant Methicillin (MRSA) has been reported, which has caused various infections both in the hospital environment and in the community; it has been considered of relevant negative impact on public health. Likewise, resistant strains have been isolated in food and food handlers, which has guided the 
implementation of hygiene measures and epidemiological studies (Cerqueira and Almeida, 2013; Cervantes-García et al., 2014b; Peña et al., 2015; Macedo et al., 2016).

In aquatic environments and food production systems such as aquaculture and because of the use of antibiotics, it allows both saprophytic and pathogenic microorganisms to exchange resistance genetic material, constituting that a risk to human health (Sáenz et al., 2019; Puig Peña et al., 2019). In various studies around the world, isolates of bacteria resistant to various antimicrobials, including Staphylococcus aureus, have been reported from fish and shellfish, reflecting the presence of this phenomenon and the health risk associated with these foods (Albuquerque et al., 2007; Atyah et al., 2010; Soliman et al., 2014; Tiamiyu et al., 2015; Boss et al., 2016; Puig Peña et al., 2019).

Among the actions to combat this phenomenon, to prevent its development and reduce its spread, international organizations, such as FAO, have established codes and guidelines (CAC/RCP, 61-2005; CAC/GL, 77-2011). Likewise, to control this phenomenon in different phases of the food chain, codes have been developed regarding the use of veterinary drugs and their residues (CX/MRL, 22018), animal feed (CAC/RCP 54-2004) and good practices of hygiene (CXC/RCP, 1-1969; CXC, 52-2003) to be applicable in the different phases of the food chain, the latter being considered fundamental for food safety and combating antimicrobial resistance (Peña et al., 2011; Verraes et al., 2013; OMS, 2016; FAO/WHO, 2020).

\section{Conclusion}

Fish is a highly nutritious food produced and marketed around the world. However, it is very susceptible to spoilage and contamination throughout the food chain. Tilapia are fish that constitute an important source of protein in the human diet, either as fillet or whole and it is one of the species with the highest production mainly through aquaculture worldwide.

Foodborne diseases constitute a serious public health problem at a global level and where foods such as fish are mainly related to outbreaks and cases of diseases, including food poisoning.

Staphylococcus aureus is an important microorganism in human clinical and food safety because, it is capable of presenting resistance to different antimicrobials and generating different diseases, including food poisoning through contamination and consumption of food, where it has growth and generation of toxins. As it is considered a pathogen of cosmopolitan distribution and the human being one of its main reservoirs around the world, different actions have been developed and established for the surveillance, control and prevention of food contamination in the different phases of the food chain, as well as for the fight against antimicrobial resistance, such as the implementation of good hygiene practices, quality assurance systems (HACCP) and microbiological criteria for the acceptance of products for consumption with emphasis on the hygiene of food handlers and storage conditions.

\section{Acknowledgement}

We thank to CONACYT, CIBNOR and UNCIBNOR + for the facilities provided for the preparation of this manuscript.

\section{Author Contributions}

Alejandro De Jesús Cortés-Sánchez: Conception and design of the study, search, information analysis, writing of the manuscript.

Mayra Díaz-Ramírez, Ma. De la Paz SalgadoCruz and Rocío G. Hernandez-Nava: Search, information analysis, writing of the manuscript.

\section{Interest Conflict}

The authors declare that they have no conflict of interest in the development and publication of this document.

\section{References}

Abdel-Moein, K. A., Saeed, H., \& Samir, A. (2015). Novel detection of Helicobacter pylori in fish: A possible public health concern. Acta tropica, 152, 141-144.

Acha, P. N., \& Szyfres, B. (2001). Zoonosis y enfermedades transmisibles comunes al hombre ya los animales. Organización Panamericana de la Salud.

Albuquerque, W. F., Macrae, A., Sousa, O. V., Vieira, G. H. F., \& Vieira, R. H. S. F. (2007). Multiple drug resistant Staphylococcus aureus strains isolated from a fish market and from fish handlers. Brazilian Journal of Microbiology, 38(1), 131-134.

Alerte, V., Cortés, A. S., Díaz, T. J., Vollaire, Z. J., Espinoza, M. M., Solari, G. V., ... \& Torres, H. M. (2012). Foodborne disease outbreaks around the urban Chilean areas from 2005 to 2010. Revista chilena de infectologia: organo oficial de la Sociedad Chilena de Infectologia, 29(1), 26-31.

Ali, H. H. (2014). Isolation and identification of Staphylococcus bacteria from fish of fresh water and its antibiotics sensitivity in mosul city. Basrah Journal of Veterinary Research., 13(1), 33-42.

Arfatahery, N., Davoodabadi, A., \& Abedimohtasab, T. (2016). Characterization of toxin genes and antimicrobial susceptibility of Staphylococcus aureus isolates in fishery products in Iran. Scientific reports, 6(1), 1-7. 
Arteaga Bonilla, R., \& Arteaga Michel, R. (2005). Infecciones estafilocócicas. Revista de la Sociedad Boliviana de Pediatría, 44(3), 178-180.

Atyah, M. A. S., Zamri-Saad, M., \& Siti-Zahrah, A. (2010). First report of methicillin-resistant Staphylococcus aureus from cage-cultured tilapia (Oreochromis niloticus). Veterinary microbiology, 144(3-4), 502-504.

Baltazar, P. M. (2007). La Tilapia en el Perú: acuicultura, mercado, y perspectivas. Revista peruana de biología, 13(3), 267-273.

Barreto Argilagos, G., Sedrés Cabrera, M., Rodríguez Torrens, H., \& Guevara Viera, G. (2010). Bacterial agents associated to foodborne outbreaks in Camaguiey, Cuba, in the period 2000-2008. REDVET, 11(2).

Becerra, G., Plascencia, A., Luévanos, A., Domínguez, M., \& Hernández, I. (2009). Mecanismo de resistencia a antimicrobianos en bacterias. Enfermedades Infecciosas y Microbiología, 29(2), 70-76.

Boari, C. A., Pereira, G. I., Valeriano, C., Silva, B. C., Morais, V. M. D., Figueiredo, H. C. P., \& Piccoli, R. H. (2008). Bacterial ecology of tilapia fresh fillets and some factors that can influence their microbial quality. Food Science and Technology, 28(4), 863-867.

Boss, R., Overesch, G., \& Baumgartner, A. (2016). Antimicrobial resistance of Escherichia coli, Enterococci, Pseudomonas aeruginosa and Staphylococcus aureus from raw fish and seafood imported into Switzerland. Journal of food protection, 79(7), 1240-1246.

Brizzio, A. A., Tedeschi, F. A., \& Zalazar, F. E. (2011). Descripción de un brote de intoxicación alimentaria estafilocócica ocurrido en Las Rosas, Provincia de Santa Fe, Argentina. Revista argentina de microbiología, 43(1), 28-32.

Brizzio, A. A., Tedeschi, F. A., \& Zalazar, F. E. (2013). Estrategia de PCR múltiple para la caracterización molecular simultánea de Staphylococcus aureus y enterotoxinas estafilocócicas en aislamientos de brotes de origen alimentario. Biomédica, 33(1), 122-127.

Bujjamma, P., \& Padmavathi, P. (2015). Prevalence of Staphylococcus aureus in fish samples of local domestic fish market. Int. J. Curr. Microbiol. App. Sci, 4(5), 427-433.

CAC/GL. (77-2011). Guidelines for risk analysis of foodborne antimicrobial resistance. Geneva: Food and Agriculture Organization.

CXC (52-2003). Code of practice for fish and fishery products. Codex Alimentarius. Food and Agriculture Organization of the United Nations FAO. World Health Organization WHO.
CXC/RCP. (1-1969). General principles of food hygiene. Food and Agriculture Organization of the United Nations FAO. World Health Organization WHO. Codex Alimentarius.

CAC/RCP. (54-2004). Code of practice on good animal feeding. Food and Agriculture Organization of the United Nations FAO. World Health Organization WHO. Codex alimentarius.

CAC/RCP. (61-2005). Code of practice to minimize and contain antimicrobial resistance. Food and Agriculture Organization of the United Nations FAO. World Health Organization WHO. Codex alimentarius.

Cáceres, E. X. U., Becerra, A. M. A., \& Bernal, C. P. J. (2017). Determinación del perfil de susceptibilidad a antibióticos de Listeria sp. aisladas de leche cruda de vaca en Tunja. Revista Investigación en Salud Universidad de Boyacá, 4(1), 38-52.

Calderón Rojas, G., \& Aguilar Ulate, L. (2016). Resistencia antimicrobiana: microorganismos más resistentes $\mathrm{y}$ antibióticos con menor actividad. Revista Médica de Costa Rica Y Centroamérica, 73(621), 757-763.

Cerqueira, E. S., \& Almeida, R. C. D. C. (2013). Staphylococcus aureus resistente à meticilina (MRSA) em alimentos de origem animal: uma revisão sistemática. Revista do Instituto Adolfo Lutz, 72(4), 268-281.

Cervantes-García, E., García-González, R., \& SalazarSchettino, P. M. (2014a). Características generales del Staphylococcus aureus. Revista Mexicana de Patología Clínica y Medicina de Laboratorio, 61(1), 28-40.

Cervantes-García, E., García-González, R., \& SalazarSchettino, P. M. (2014b). Importancia de Staphylococcus aureus meticilina resistente intrahospitalario y adquirido en la comunidad. Revista Mexicana de Patología Clínica y Medicina de Laboratorio, 61(4), 196-204.

CX/MRL. (2-2018). Maximum Residue Limits (MRLs) and risk management recommendations (RMRs) for residues of veterinary drugs in foods. Food and Agriculture Organization of the United Nations FAO. World Health Organization WHO. Codex alimentarius.

da Rocha, F. A. G., de Araújo, L. O., Alves, K. S., Dantas, L. Í. S., da Silva, R. P., \& de Araújo, M. F. F. (2013). Estafilococos Coagulase Positivos Em Filés De Tilápia (Oreochromis Niloticus) comercializados no mercado modelo nerival araújo, currais novos/RN. Holos, 1, 84-91.

Cortés Sánchez, A. D. J., Díaz Ramirez, M., Garcia Barrientos, R., \& Sharma, A. (2017). The genus Staphylococcus: Harmful and Beneficial Microorganisms in the Environment. Pakistan Journal of Life \& Social Sciences, 15(2), 72-83. 
De la Fuente Salcido, N. M., \& Corona, J. E. B. (2010). Inocuidad y bioconservación de alimentos. Acta universitaria, 20(1), 43-52.

Directive, C. (1996). Council Directive 96/23/EC of 29 April 1996 on measures to monitor certain substances and residues thereof in live animals and animal products and repealing Directives 85/358/EEC and 86/469/EEC and Decisions 89/187/EEC and 91/664/EEC. OJ EC L, 125, 10-31.

Echandi, M. L. A., \& Ulate, C. C. (2012). Calidad microbiológica de la materia prima y el producto final del ceviche de tilapia y de camarón expendidos en el Área Metropolitana de San José, Costa Rica. UNED Research Journal, 4(1), 85-92.

Elika. (2020). Staphylococcus aureus. Fundación Vasca para la Seguridad Agroalimentaria (ELIKA). https://seguridadalimentaria.elika.eus/staphylococcu s-aureus/

Elmahdi, S., DaSilva, L. V., \& Parveen, S. (2016). Antibiotic resistance of Vibrio parahaemolyticus and Vibrio vulnificus in various countries: a review. Food microbiology, 57, 128-134.

Espinosa, L., Varela, C., Martínez, E. V., \& Cano, R. (2015). Brotes de enfermedades transmitidas por alimentos. España, 2008-2011 (excluye brotes hídricos). Boletín epidemiológico semanal, 22(11), 130-136.

FAO/WHO. (2020). Antimicrobial Resistance. Food and Agriculture Organization of the United Nations FAO. World Health Organization WHO. Codex Alimentarius.

Farias, M. D. C. A., \& Freitas, J. D. A. (2008). Qualidade microbiológica de pescado beneficiado em indústrias paraenses. Revista do Instituto Adolfo Lutz (Impresso), 67(2), 113-117.

Figueroa, G., Navarrete, P., Caro, M., Troncoso, M., \& Faúndez, G. (2002). Carriage of enterotoxigenic Staphylococcus aureus in food handlers. Revista médica de Chile, 130(8), 859-864.

Fitzsimmons, K. (2008). Food safety, quality control in tilapia products. Global Advocate, 32-34.

Fuentes, M., Valladares, J., Grass, G., \& Pico, Y. (2011). Microbial of the public health interest of Oreochromis spp.(red tilapia) cultured in fresh water floating cages. Revista Cubana de Investigaciones Pesqueras, 28(2), 74-80.

Fuertes Vicente, H. G., Paredes López, F., \& Saavedra Gálvez, D. I. (2014). Good practice manufacturing and preservation on board: fish safe. Revista big ban faustiniano, 3(4), 40-45.

Gestal, M. C., Villacís, J. E., Alulema, M. J., \& Chico, P. (2014). De la granja a la mesa. Implicaciones del uso de antibióticos en la crianza de animales para la resistencia microbiana y la salud. Revista Cubana de Alimentación y Nutrición, 24(1), 11.
González Ayala, S. E., \& Cecchini, D. M. (2020). Enfermedades Bacterianas Transmitidas por Alimentos. Módulo 2. Diagnostico e investigación epidemiológica de las enfermedades transmitidas por alimentos. Organización Panamericana de la Salud/ Pan American Health Organization/World Health Organization: PAHO/WHO. https://www.paho.org/arg/publicaciones/publicacion es\%20virtuales/libroetas/modulo2/modulo2n.html

González Flores, T. \& Rojas Herrera R. A. (2005). Enfermedades transmitidas por alimentos y PCR: prevención y diagnóstico. Salud pública de México, 47(5),

388-390. https://www.scielosp.org/pdf/spm/2005.v47n5/388390/es

González-Muñoz, Y., \& Palomino-Camargo, C. E. (2012). Acciones para la gestión de la calidad sanitaria e inocuidad de los alimentos en un restaurante con servicio bufet. Revista Gerencia y Políticas de Salud, 11(22), 123-140.

Goulding, I. C. (2016). Manual para garantizar la seguridad alimentaria de los productos de la Acuicultura, CRFM Publicación Especial No.10, pp.17. Traducido por Oscar do Porto, 2016. Titulo original: Manual on Assuring the Food Safety of Aquaculture Products.

Gutiérrez-Guzmán, N., Dussan-Sarria, S., Osorio, I., \& Sánchez, J. (2017). Identificación de peligros que afectan la inocuidad en una planta de procesamiento de tilapia roja: Un estudio de caso. Interciencia, 42(4), 224-228.

Huss, H. H. (1997). Aseguramiento de la calidad de los productos pesqueros. FAO Documento Técnico de Pesca. No. 334. Organización de las Naciones Unidas para la Agricultura y la Alimentación (FAO). Roma (Italia).

Huss, H. H. (1998). El pescado fresco: su calidad y cambios de su calidad. FAO documento tecnico de pesca 348. Organización de las Naciones Unidas para la Agricultura y la Alimentación (FAO).

Hussein, M. A., Merwad, A. M., Elabbasy, M. T., Suelam, I. I., Abdelwahab, A. M., \& Taha, M. A. (2019). Prevalence of enterotoxigenic Staphylococcus aureus and Shiga toxin producing Escherichia coli in fish in Egypt: quality parameters and public health hazard. Vector-Borne and Zoonotic Diseases, 19(4), 255-264.

INP. (2018). Acuacultura. Tilapia. Instituto Nacional de Pesca (INP). Gobierno de México. https://www.gob.mx/inapesca/acciones-yprogramas/acuacultura-tilapia 
ISO 6888-1:1999/AMD. (2018). Microbiology of food and animal feeding stuffs - Horizontal method for the enumeration of coagulase-positive staphylococci (Staphylococcus aureus and other species) - Part 1: Technique using Baird-Parker agar medium Amendment 2: Inclusion of an alternative confirmation test using RPFA stab. ISO (the International Organization for Standardization)

ISO 6888-2. (1999). Microbiology of food and animal feeding stuffs-Horizontal method for the enumeration of coagulase-positive staphylococci (Staphylococcus aureus and other species) — Part 2: Technique using rabbit plasma fibrinogen agar medium. ISO (the International Organization for Standardization)

ISO 6888-3, (2003). Microbiology of food and animal feeding stuffs - Horizontal method for the enumeration of coagulase-positive staphylococci (Staphylococcus aureus and other species) - Part 3: Detection and MPN technique for low numbers. ISO (the International Organization for Standardization)

Jácome, J., Quezada Abad, C., Sánchez Romero, O., Pérez, J. E., \& Nirchio, M. (2019). Tilapia en Ecuador: paradoja entre la producción acuícola y la protección de la biodiversidad ecuatoriana. Revista peruana de biología, 26(4), 543-550.

Jorda, G. B., Marucci, R. S., Guida, A. M., Pires, P. S., \& Manfredi, E. A. (2012). Carriage and characterization of Staphylococcus aureus in food handlers. Revista Argentina de Microbiologia, 44(2), 101-104.

Jorquera, D., Galarce, N., \& Borie, C. (2015). El desafío de controlar las enfermedades transmitidas por alimentos: bacteriófagos como una nueva herramienta biotecnológica. Revista chilena de infectología, 32(6), 678-688.

Junior, P. G., Assunção, A. W., Baldin, J. C., \& Amaral, L. A. (2014). Microbiological quality of whole and filleted shelf-tilapia. Aquaculture, 433, 196-200.

Junod, T., López-Martin, J., \& Gädicke, P. (2013). Estudio de susceptibilidad antimicrobiana de Salmonella enterica en muestras de origen animal y alimentario. Revista médica de Chile, 141(3), 298-304.

Kang, L., Petersen, G., Barco, L., Hvidtfeldt, K., Liu, L., \& Dalsgaard, A. (2017). Salmonella Weltevreden in integrated and non-integrated tilapia aquaculture systems in Guangdong, China. Food Microbiology, $65,19-24$.

Kopper, G., Calderón, G., Schneider, S., Domínguez, W., Gutiérrez, G., Rosell, C., \& Mejía, D. (2009). Enfermedades transmitidas por alimentos y su impacto socioeconómico. Informe de la Organización de las Naciones Unidas para la agricultura y la alimentación. Roma, Italia: FAO, 6, 1-194.
Lerma-Fierro, A. G., Flores-López, M. K., GuzmánRobles, M. L., \& Cortés-Sánchez, A. D. J. (2020). Microbiological evaluation of minimally processed and marketed fish in popular market of the city of Tepic Nayarit, Mexico Sanitary quality of tilapia (Oreochromis niloticus). Tropicultura.

Macedo, V. F., Zanardo, J. G., Lopes, R. P. C., Mendonça, H. F. M. S., Eaymundo, N. L. S., \& Moraes, R. (2016). Prevalência de coliformes e Staphylococcus aureus em mãos de manipuladores de alimentos de feira livre de Vitória-ES. Salus Journal Health Science, 2(2), 27-38.

Macori, G., Bellio, A., Bianchi, D. M., Gallina, S., Adriano, D., Zuccon, F., ... \& Decastelli, L. (2016). Molecular typing of Staphylococcus aureus isolate responsible for staphylococcal poisoning incident in homemade food. Italian Journal of Food Safety, 5(2).

Manfredi, E. A., Leotta, G. A., \& Rivas, M. (2010). Multiplex PCR for the detection of sea, seb, sec, sed and see genes of Staphylococcus aureus: characterization of isolates from food. Revista Argentina de Microbiologia, 42(3), 212-215.

MINSA. (2007). Resolución ministerial $\mathrm{N}^{\mathrm{o}} 461$ 2007/MINSA. Guía técnica para el análisis microbiológico de superficies en contacto con alimentos y bebidas. Normas legales. Perú.

Morales, G., Blanco, L., Arias, M. L., \& Chaves, C. (2004). Evaluación de la calidad bacteriológica de tilapia fresca (Oreochromis niloticus) proveniente de la Zona Norte de Costa Rica. Archivos latinoamericanos de nutricion, 54(4), 433-437.

NMX-F-310-1978. Determinación de cuenta de Staphylococcus aureus coagulasa positiva, en alimentos. Method of test for count of Staphylococcus aureus in food. Normas mexicanas. Dirección general de normas. https://www.colpos.mx/bancodenormas/nmexicanas/ NMX-F-310-1978.PDF

NMX-F-605-NORMEX-2016. Alimentos - manejo higienico en el servicio de alimentos preparados para la obtención del distintivo "H". foods hygienic handling in the service of prepared food to obtain the "h" distinctive. (Esta Norma cancela la NMX-F-605-NORMEX-2004).

NOM-210-SSA1-2014. Productos y servicios. Métodos de prueba microbiológicos. Determinación de microorganismos indicadores. Determinación de microorganismos patógenos. Norma Oficial Mexicana. Gobierno de México. http://dof.gob.mx/nota_detalle.php?codigo=5398468 $\&$ fecha $=26 / 06 / 2015$ 
NOM-242-SSA1-2009. Productos y servicios. Productos de la pesca frescos, refrigerados, congelados $y$ procesados. Especificaciones sanitarias y métodos de prueba. Norma Oficial Mexicana

NOM-251-SSA1-2009. Prácticas de higiene para el proceso de alimentos, bebidas o suplementos alimenticios. Norma Oficial Mexicana. Gobierno de México.

http://www.fao.org/faolex/results/details/es/c/LEXFAOC093118/

OJEU. (2002). Regulation (EC) No 178/2002 of the European parliament and of the council of 28 January 2002. Laying down the general principles and requirements of food law, establishing the European Food SafetyAuthority and laying down procedures in matters of food safety. Official Journal of the European Communities.

OJEU. (2004a). Regulation (EC) No 852/2004 of the European parliament and of the council of 29 April 2004 on the hygiene of foodstuffs. Official Journal of the European Union.

OJEU. (2004b). Regulation (EC) No 853/2004 of the European parliament and of the council of 29 April 2004 laying down specific hygiene rules for on the hygiene of foodstuffs. Official Journal of the European Union. https://eur-lex.europa.eu/legalcontent/EN/TXT/PDF/?uri=CELEX:32004R0853\&f rom $=\mathrm{ES}$

OJEU. (2004c). Regulation (EC) No 854/2004 of the European parliament and of the council of 29 April 2004 laying down specific rules for the organization of official controls on products of animal origin intended for human consumption. Official Journal of the European Union. https://eur-lex.europa.eu/legal-

content/EN/TXT/PDF/?uri=CELEX:32004R0854 $\&$ from $=\mathrm{ES}$

OJEU. (2004d). Regulation (EC) No 882/2004 of the European parliament and of the council of 29 April 2004 on official controls performed to ensure the verification of compliance with feed and food law, animal health and animal welfare rules. Official Journal of the European Union. https://eurlex.europa.eu/legal-

content/EN/TXT/PDF/?uri=CELEX:32004R0882\&f rom=es

OJEU. (2005). Regulation (EC) No 2073/2005 of 15 November 2005 on microbiological criteria for foodstuffs. Official Journal of the European Union.

Olea, A., Diaz, J., Fuentes, R., Vaquero, A., \& Garcia, M. (2012). Foodborne disease outbreaks surveillance in Chile. Revista chilena de infectologia: organo oficial de la Sociedad Chilena de Infectologia, 29(5), 504-510.
OMS. (2016). Cinco claves para una mayor inocuidad de los productos de acuicultura con objeto de proteger la salud pública. ISBN $978 \quad 92 \quad 4 \quad 351031 \quad 6$. Organización Mundial de la Salud (OMS) / World Health Organization (WHO). https://apps.who.int/iris/bitstream/handle/10665/251 672/9789243510316-spa.pdf

OMS. (2007). Manual sobre las cinco claves para la inocuidad de los alimentos. Organización mundial de la salud (OMS)/World Health Organization (WHO). https://www.who.int/foodsafety/publications/consu mer/manual_keys_es.pdf?ua=1

Palomino-Camargo, C., \& González-Muñoz, Y. (2014). Molecular techniques for detection and identification of pathogens in food: advantages and limitations. Revista peruana de medicina experimental y salud publica, 31(3), 535-546.

Peña, Y. P., Hernández, M. E., \& Castillo, V. L. (2011). Resistencia antimicrobiana en Salmonella y E. coli aisladas de alimentos: revisión de la literatura. Panorama. Cuba y Salud, 6(1), 30-38.

Peña, Y. P., Hernández, M. E., Castillo, V. L., López, N. A., Muñoz, Y. P., \& Rodríguez, P. S. (2015). Resistencia antimicrobiana en cepas de estafilococos coagulasa positiva aisladas en alimentos y manipuladores. Revista Cubana de Alimentación y Nutrición, 25(2), 245-260.

Puig Peña, Y., Leyva Castillo, V., Aportela López, N., Camejo Jardines, A., \& Tejedor Areas, R. (2019). Resistencia antimicrobiana en bacterias aisladas de pescados y mariscos. Revista Habanera de Ciencias Médicas, 18(3), 500-512.

Romero-Jarero, J. M., \& Negrete-Redondo, M. D. P. (2011). Presencia de bacterias Gram positivas en músculo de pescado con importancia comercial en la zona del Caribe mexicano. Revista mexicana de biodiversidad, 82(2), 599-606.

RTCA 67.04.50:17. ICS 67.050. (2018). 1ra Revisión. Reglamento Técnico Centroamericano Alimentos (RTCA). Criterios microbiológicos para la inocuidad de los alimentos.

SA/DM. (2003). Resolución ministerial No 615-2003SA/DM. Criterios Microbiológicos de Calidad Sanitaria e Inocuidad para los Alimentos y Bebidas de Consumo Humano.

Sáenz, J. S., Marques, T. V., Barone, R. S. C., Cyrino, J. E. P., Kublik, S., Nesme, J.,\& Vestergaard, G. (2019). Oral administration of antibiotics increased the potential mobility of bacterial resistance genes in the gut of the fish Piaractus mesopotamicus. Microbiome, 7(1), 1-14. 
SAGARPA. (2018). Atlas Agroalimentario 2012-2018. Secretaria de Agricultura, Ganadería, Desarrollo rural, Pesca y Alimentación (SAGARPA). Gobierno de México. https://nube.siap.gob.mx/gobmx_publicaciones_siap /pag/2018/Atlas-Agroalimentario-2018

Saito, E., Yoshida, N., Kawano, J., Shimizu, A., \& Igimi, S. (2011). Isolation of Staphylococcus aureus from raw fish in relation to culture methods. Journal of Veterinary Medical Science, 73(3), 287-292.

SENASICA. (2019). Manuales de Buenas Prácticas Acuícolas. Servicio Nacional de Sanidad, Inocuidad y Calidad Agroalimentaria (SENASICA). Gobierno de México. https://www.gob.mx/senasica/documentos/manuales -de-buenas-practicas-pecuarias-acuicolas-ypesqueras

Sheyin, A. N., \& Solomon, K. J. (2017). EndoMicrobial Fauna of Tilapia spp. Oreochromis niloticus, 1-8.

Shinkafi, S. A., \& Ukwaja, V. C. (2010). Bacteria Associated with Fresh Tilapia Fish (Oreochromis niloticus) Sold At Sokoto Central Market in Sokoto, Nigeria. Nigerian Journal of Basic and Applied Sciences, 18(2).

Soares, K. M. D. P., \& Gonçalves, A. A. (2012). Qualidade e segurança do pescado. Revista do Instituto Adolfo Lutz (Impresso), 71(1), 1-10.

Soliman, M. K., Ellakany, H. F., Gaafar, A. Y., Elbialy, A. K., Zaki, M. S., \& Younes, A. M. (2014). Epidemiology and antimicrobial activity of methicillin-resistant Staphylococcus aureus (MRSA) isolated from Nile tilapia (Oreochromis niloticus) during an outbreak in Egypt. Life Science Journal, 11(10), 1245-1252.

Soto Varela, Z., Pérez Lavalle, L., \& Estrada Alvarado, D. (2016). Bacterias causantes de enfermedades transmitidas por alimentos: una mirada en Colombia. Revista Salud Uninorte, 32(1), 105-122.

Sousa, C. L., Freitas, J. D. A., Lourenço, L. D. F. H., Araujo, E. A. F., \& Souza, J. N. S. D. (2011). Avaliação da qualidade microbiológica no processamento de pescados. Revista do Instituto Adolfo Lutz (Impresso), 70(2), 151-157.

Suárez-Semour, M. A., \& González, G. M. (1990). Enzymic immunoassay for the detection of enterotoxins B and C of S. aureus in milk. Salud Pública de México, 32(1), 64-73.

Tallent, S., Hait, J., Bennett, R. W., \& Lancette, G. A. (2019). BAM Chapter 12: Staphylococcus aureus. Bacteriological Analytical Manual (BAM). U.S. Food and Drug Administration (FDA). https://www.fda.gov/food/laboratory-methodsfood/bam-chapter-12-staphylococcus-aureus
Tiamiyu, A. M., Soladoye, M. O., Adegboyega, T. T., \& Adetona, M. O. (2015). Occurrence and antibiotic sensitivity of bacterial strains isolated from Nile Tilapia, Oreochromis niloticus obtained in Ibadan, Southwest Nigeria. Journal of Biosciences and Medicines, 3(05), 19.

Torrens, H. R., Argilagos, G. B., Cabrera, M. S., Valdés, J. B., Sáez, S. M., \& Viera, G. G. (2015). Las enfermedades transmitidas por alimentos, un problema sanitario que hereda e incrementa el nuevo milenio. REDVET. Revista Electrónica de Veterinaria, 16(8), 1-27.

USDA. (2020). Quantitative Analysis of Bacteria in Foods as Sanitary Indicators (MLG 3.02). The Microbiology Laboratory Guidebook (MLG). Food Safety and Inspection Service (FSIS). Office of Public Health Science (OPHS). United States Department of Agriculture (USDA). https://www.fsis.usda.gov/wps/wcm/connect/f21620 91-af72-4888-997b-718d6592bcc9/MLG3.pdf?MOD=AJPERES

Vázquez-Sánchez, D., Galvao, J. A., \& Oetterer, M. (2018). Contamination sources, biofilm-forming ability and biocide resistance of Staphylococcus aureus in tilapia-processing facilities. Food Science and Technology International, 24(3), 209-222.

Ampuero, J. M. V., Alcántara, W. R. T., Talenas, M. Á. C., \& Sotil, S. A. (2018). Evaluación microbiológica de pescados y mariscos expendidos en mercados de la ciudad de Huánuco. Investigación Valdizana, 12(2), 75-82.

Verraes, C., Van Boxstael, S., Van Meervenne, E., Van Coillie, E., Butaye, P., Catry, B., ... \& Daube, G. (2013). Antimicrobial resistance in the food chain: a review. International journal of environmental research and public health, 10(7), 2643-2669.

Wakabayashi, Y., Umeda, K., Yonogi, S., Nakamura, H., Yamamoto, K., Kumeda, Y., \& Kawatsu, K. (2018). Staphylococcal food poisoning caused by Staphylococcus argenteus harboring staphylococcal enterotoxin genes. International journal of food microbiology, 265, 23-29.

Weiler, N., Orrego, M., Alvarez, M., Huber, C., Ortiz, F., Nuñez, L., ... \& Perez, J. (2017). Primeros resultados de la vigilancia integrada de la resistencia antimicrobiana de patógenos transmitidos por alimentos, Campylobacter spp. y Salmonella spp. en tres poblaciones distintas. Paraguay. 2011-2012. Memorias del Instituto de Investigaciones en Ciencias de la Salud, 15(2).

WHO. (2020a). Health topics.Foodborne diseases. World Health Organization (WHO). https://www.who.int/health-topics/foodbornediseases\#tab=tab_1 
Alejandro De Jesús Cortés-Sánchez et al. / OnLine Journal of Biological Sciences 2020, 20 (4): 291.306 DOI: 10.3844/ojbsci.2020.291.306

WHO. (2020b). Infographics: Estimates of the global burden of foodborne diseases Global. World Health Organization (WHO) https://www.who.int/foodsafety/areas_work/foodbor ne-diseases/ferg_infographics/en/
Zendejas-Manzo, G. S., Avalos-Flores, H., \& SotoPadilla, M. Y. (2014). Microbiología general de Staphylococcus aureus: Generalidades, patogenicidad y métodos de identificación. Revista Biomédica, 25(3), 129-143. 